\title{
Evaluation of Rare Antinuclear Antibody Patterns in a Tertiary Hospital in İzmir
}

\author{
Aslı Gamze Sener ${ }^{1}$ \\ 'Izmir Katip Celebi University Ataturk Training and Research Hospital, Medical Microbiology, Izmir, Turkey \\ Address for Correspondence: Asli Gamze Sener, E-mail: agsener@gmail.com \\ Received: 23.11.2017; Accepted: 12.04.2018; Available Online Date: 30.05.2018 \\ (C) Copyright 2018 by Dokuz Eylül University, Institute of Health Sciences - Available online at www.jbachs.org \\ Cite this article as: Sener AG. Evaluation of Rare Antinuclear Antibody Patterns In A Tertiary Hospital In Izmir.J Basic Clin Health Sci 2018; 2:53-56. https://doi.org/10.30621/ \\ jbachs. 2018.408
}

\begin{abstract}
Objective: Antinuclear antibody (ANA) patterns are evaluated as nuclear, cytoplasmic or mitotic on HEp-2 cel I. Although some ANA patterns have been comprehensively studied such as homogenous, speckled or nucleolar staining patterns, rare antinuclear antibody patterns still require further assessment. In this study, the rare pattern was defined as $1 \%$ occurring ratio on indirect immunofluorescence assay. Rare ANA patterns were evaluated in a 6-year period retrospectively.

Material and methods: The study includes 41921 serum samples that different departments had sent to the tertiary Hospital's Laboratory of Medical Microbiology for ANA test between January 2010 and December 2015. Serum samples were studied in dilution of 1:100 using HEp20-10/liver biochip (Monkey) and conjugated with specific antihuman IgG (Euroimmun AG, Lubeck, Germany). The fluorescence intensity was evaluated at $\times 400$ by immunofluorescence microscope (Eurostar III plus). Evaluation was performed as semi-quantitatively from 1+ to 4+. Positive (+4) and negative control were used.

Results: Of these samples, 9908 (23.6\%) were ANA-IIF-positive. Totally 168 samples were considered as rare autoantibody. Rare patterns were consisted of $49(0.49 \%)$ midbody, $29(0.29 \%)$ centriole, $20(0.20 \%)$ spindle fibers, $21(0.21 \%)$ anti-golgi, $37(0.37)$ anti-actin, $3(0.03 \%)$ rods and rings, and $9(0.09 \%)$ PCNA(proliferating cell nuclear antigen)-like. The number of females and males who have rare antibody was 101 and 67 , respectively. All of the samples presented a fluorescence of $\geq 2+$. There were 29 patients with systemic autoimmune diseases (SAID) from the rheumatology department. Another 139 patients were from gastroenterology, endocrinology, neurology and general internal medicine departments.

Conclusion: This article shared 6-year experience associated with rare ANA patterns. The significance of our results also emanates from the fact that they document a tertiary hospital's epidemiological data in Turkey.
\end{abstract}

Key words: Antinuclear antibody; rare autoantibody; immunofluorescence pattern

\section{Introduction}

Antinuclear antibody (ANA) can be helper to the diagnosis of systemic autoimmune diseases (SAID) and to monitor disease activity. Detection of ANA is essential to sub-classify patients with autoimmune disease. Although some ANA patterns have been comprehensively studied such as homogenous, nuclear or nucleolar staining patterns, rare antinuclear antibody patterns still require further assessment. Major limitations are the low frequency of the patterns, and circumscribed reports. Rare ANA patterns can be associated with some non-autoimmune conditions or SAID (1). This article seeks to scrutinize the studies and results associated with the prevalence and clinical significance of rare ANA patterns. Previously, our laboratory reported articles focusing on 4-year ANA results (2), and frequency of dense fine speckled pattern (3). Nonetheless, in our laboratory, rare ANA patterns have not been screened before. This article documents 6-year observation about rare ANA patterns in a medical microbiology laboratory of a tertiary hospital in Turkey. Evaluation of rare ANA patterns may be helper to clinical diagnosis. In laboratory practice, rare patterns should be an important part of microscopic evaluation. In this study, the rare pattern was defined as $1 \%$ occurring ratio on indirect immunofluorescence assay (IIF). The research was performed according to the World Medical Association Declaration of Helsinki.

\section{Material and Methods}

This study includes 41921 serum samples that different departments had sent to the tertiary Hospital's Laboratory of Medical Microbiology for ANA test between January 2010 and December 2015. In the study, first samples were included for each patient. Serum samples were studied in dilution of 
1:100 using HEp-20-10/liver biochip (Monkey) and conjugated with specific antihuman IgG (Euroimmun AG, Lubeck, Germany). The fluorescence intensity was evaluated at $x 400$ by immunofluorescence microscope (Eurostar III plus). Evaluation was performed as semi-quantitatively from $1+$ to $4+$. Positive $(+4)$ and negative control were used. All of the slides were evaluated by same specialist. Clinical data were collected from medical records. IBM SPSS Statistics software version 24.0 and independent sample $\mathrm{t}$ test were used in statistical analysis.

\section{Results}

Of these samples, 9908 (23.6\%) were ANA-IIF-positive. Totally 168 samples were considered as rare autoantibody. Rare patterns were consisted of 49 (0.49\%) midbody, 29 (0.29\%) centriole, 20 (0.20\%) spindle fibers, 21 (0.21\%) anti-golgi, 37 (0.37\%) anti-actin, $3(0.03 \%)$ rod and rings, and $9(0.09 \%)$ PCNA (proliferating cell nuclear antigen)-like (Table 1). All of the samples presented a fluorescence of $\geq 2+$. There were 29 patients with SAID and other diagnosis from the rheumatology department. SAID contains systemic lupus erythematosus (SLE), systemic sclerosis (SSc), mixed connective tissue disease (MCTD) and Sjögren's syndrome (SjS). Another 139 patients were from gastroenterology, endocrinology, neurology, infectious diseases, ophthalmology and general

\begin{tabular}{|c|c|c|c|c|}
\hline IIF Pattern & $\mathbf{n}$ & $\%$ & Diagnosis & $\mathbf{n}$ \\
\hline Midbody & 49 & 0.49 & $\begin{array}{l}\text { Cancer (esophageal, gastric, colon) } \\
\text { SAID } \\
\text { Polyneuropathy } \\
\text { Infectious disease } \\
\text { Postmenopausal osteoporosis } \\
\text { Other pathologies }\end{array}$ & $\begin{array}{c}22 \\
12 \\
3 \\
3 \\
1 \\
8\end{array}$ \\
\hline Anti-actin & 37 & 0.37 & $\begin{array}{l}\text { Autoimmune hepatitis/Primary } \\
\text { biliary cirrhosis/Chronic liver disease } \\
\text { Celiac disease }\end{array}$ & 36 \\
\hline Centriole & 29 & 0.29 & $\begin{array}{l}\text { SAID } \\
\text { Cerebrovascular disease } \\
\text { Other pathologies }\end{array}$ & $\begin{array}{l}14 \\
8 \\
7\end{array}$ \\
\hline Anti-golgi & 21 & 0.21 & $\begin{array}{l}\text { SAID } \\
\text { Chronic liver disease } \\
\text { Infectious disease } \\
\text { Other pathologies }\end{array}$ & $\begin{array}{l}2 \\
9 \\
4 \\
6\end{array}$ \\
\hline Spindle fibers & 20 & 0.20 & $\begin{array}{l}\text { Infectious disease } \\
\text { Cancer } \\
\text { Vasculitis } \\
\text { Diabetes mellitus type } 2 \\
\text { Autoimmune hepatitis } \\
\text { Other pathologies }\end{array}$ & $\begin{array}{l}5 \\
3 \\
2 \\
2 \\
1 \\
7\end{array}$ \\
\hline PCNA-like & 9 & 0.09 & $\begin{array}{l}\text { Infectious disease } \\
\text { Polyneuropathy } \\
\text { SAID } \\
\text { Other pathologies }\end{array}$ & $\begin{array}{l}2 \\
2 \\
1 \\
4\end{array}$ \\
\hline Rods and rings & 3 & 0.03 & Chronic hepatitis C & 3 \\
\hline
\end{tabular}

SAID: Systemic autoimmune diseases.

PCNA: Proliferating cell nuclear antigen.
Table 2. Diagnosis and departments of the patients that have rare ANA pattern

\begin{tabular}{ll}
\hline Department & Pre-diagnosis/diagnosis \\
\hline Rheumatology & SAID \\
& $\begin{array}{l}\text { Postmenopausal osteoporosis } \\
\text { Ankylosing spondylitis } \\
\text { Hepatic fibrosis }\end{array}$ \\
Cholangitis \\
Cancer (esophageal, gastric, colon) \\
Chronic hepatitis \\
Endocrinology & Diabetes mellitus type 2 \\
Cerebrovascular disease \\
Infectious diseases & $\begin{array}{l}\text { Polyneuropathy } \\
\text { Ophthalmology }\end{array}$ \\
General internal medicine & Keratitis \\
\hline
\end{tabular}

SAID: Systemic autoimmune diseases.

internal medicine departments (Table 2). The analyzed 168 patients with rare ANA included 107 females and 61 males. The mean age was $56.74 \pm 8.09$ in females and $59.00 \pm 5.38$ in males. The mean age of female cases was smaller than that of male cases and it was statistically significant $(p<0.05)$.

\section{Discussion}

Rare autoantibody patterns were evaluated as mitotic (midbody, spindle fibers, centriole and rod and rings), nuclear (PCNA-like) and cytoplasmic (anti-golgi, anti-actin) in our retrospective analyses. The midbody pattern was the most prevalent autoantibody in our study. The midbody is occurred in the final phase of cell division and it includes microtubuli related to the spindle mid-zone and certain associated proteins $(1,4,5)$. Fang et al. (6) have investigated autoantibodies in the serum samples of primary hepatocarcinoma patients. They informed that the positivity rate of autoantibodies was $27.3 \%$ (38/139) in 139 patients. Anti-midbody antibody was detected in 1 patient (1/38, 2.6\%). Vermeersch and Bossuyt (1) have informed that an unclear nuclear speckled staining is observable in interphase cells. In addition, this pattern is related with SjS, Raynaud's syndrome and cancer. In their retrospective analysis, they have reported 12 patients with midbody pattern and 5 patients had cancer. In our evaluation, 22 of 49 patients who have midbody pattern were gastrointestinal system cancer such as esophageal, gastric or colon.

Smooth muscle antibodies (SMA) and antinuclear antibodies are significant markers in the serological diagnosis of autoimmune hepatitis type 1 (AIH-1). SMA staining patterns for $\mathrm{AlH}-1$ correlate with filamentous actin (F-actin) (7). A lot of articles have been published associated with anti-actin antibodies in $\mathrm{AlH}-1$ patients $(8,9,10)$. In our analysis clinical diagnosis of 36 patients were associated with liver diseases.

In animal cells, there is an essential microtubule organizing center during interphase and mitosis. It is composed of centrosome matrix or pericentriolar material. The structure is termed as centrosome $(1,11)$. The centrioles are part of centrosome. Anticentriole antibodies have been observed rarely and reported 
in patients with different systemic autoimmune disorders such as SjS, SLE, SSc. It may be seen inthe patients with viral or mycoplasmal infections (12). In Vermeersch P et al.'s article (1), the anti-centriole pattern was the rarest autoantibody pattern. Our results were different from the investigation in terms of case count. They reported anti-centriole antibody for six patients in 12-year period whereas we report 29 patients in 6-year period. This difference can be attributed to variations in Hep- 2 cell series in conjunction with improvements in diagnosis technology and capabilities. In addition, epidemiological differences including patient population and geographical location might have played significant role in leading the difference in our results. However, Hamaguchi et al. (13) informed 5 scleroderma patients with anticentriole antibody. They emphasized that anti-centrioleantibodies may help the diagnosis ofpulmonary arterial hypertension and digital ulcers or gangrene. Terreri et al. (14) have reported a case. They observed anti-centriole autoantibodies in a 49-year-old patient with acute thromboangiitis obliterans, several vascular risk factors and associated features of collagen vascular disease. We detected 8 patients with cerebrovascular disease in our analysis.

Rodriguez et al. (15) first reported anti-golgi antibodies in a patient with Sjögren's syndrome and lymphoma. Anti-golgi antibodies give a characteristic speckled staining on IIF comprised of irregular granules contiguous to one side of the nucleus (11). A lot of investigators reported cases with anti-golgi antibody that have autoimmune disease $(15,16,17)$. However, Hong et al. (18) informed that most of the anti-golgi antibody-positive cases were found to be patients with non-autoimmune diseases (8/12 patients) in their evaluation. They emphasized that anti-golgi antibodies associated with clinical diseases require further assessment. In our evaluation there were 2 patients with SAID. There were additional antibodies such as SCl, SSA and SSB in immunoblotting assay in the patients. Similarly, Hattori et al. (19) reported a 74-year-old woman with anti-golgi antibody and anti-SS-A/Ro antibody who contracted inflammatory myopathy. Additionally, Mozo et al. (20) have firstly described a patient with hepatitis $C$ virus-induced hepatocellular carcinoma, who has high titres of anti-golgi antibodies. There were 9 similar patients with chronic liver disease due to hepatitis B or C virus in the current study.

Mitotic apparatus proteins are responsible for specific functions during mitosis and the post-mitotic period. Mitotic apparatus is comprised of some structures such as centrosomes, spindle poles, spindle microtubules, and chromosomes and intercellular bridge (11). Bonaci-Nikolic B et al. (21) reported that the Nuclear-Mitotic Apparatus protein (NuMa-1) is responsible for organization of the mitotic spindle and the major target for mitotic apparatus antigens. Since both nucleoplasmic and mitotic spindle poles are stained, NuMA might be admitted as a "composite" pattern $(11,22)$. In an article $(21)$, it has been informed that anti-mitotic apparatus antibody is one of the rare autoantibodies in patients who have symptoms related to autoimmunity. The importance of anti-mitotic apparatus antibodies should be evaluated together with clinical presentation and other systemic autoantibodies. Vermeersch P et al. (1) reported the 66 patients who have positive for anti-NuMa1 antibodies in their study. According to the analysis there were only 6 patients with systemic autoimmune disease: SLE (3 patients), SjS (1 patient) and undifferentiated connective tissue disorder (UCTD) (2 patients). Five patients were with rheumatoid arthritis. The authors informed that carcinoma was the most frequent non-autoimmune disorder related with anti-mitotic spindle apparatus antibodies. In our analysis, most of the patients that have spindle fibers pattern were from infectious diseases department. Notwithstanding, other reasons such as postmenopausal osteoporosis, cerebrovascular disease, fibromyalgia and osteoarthritis were also detected.

Miyachi et al. (23) firstly described antibodies to PCNA in some patients with SLE. Some authors have informed that anti-PCNA antibodies are rare but highly specific for $\operatorname{SLE}(24,25)$. BeyneRauzy et al. (24) analyzed 8259 ANA tests between 1995 and 2000. They have reported that 12 patients were found positive for antiPCNAs. The diagnosis of 12 patients was SLE. It has been informed that anti-PCNA antibodies may be found in more severe clinical signs (24) such as nephritis (26). As distinct from this analysis there was 1 patient, who has anti-PCNA-like, with SLE in our study. Other pathologies were gonarthrosis (2 patients), respiratory disease ( 1 patient) and atopic dermatitis ( 1 patient).

Rods and rings pattern is observed in chronic hepatitis $C$ patients. It is occurred by $\sim 3-10 \mu \mathrm{m}$ rods and $2-5 \mu \mathrm{m}$ rings on Hep-2 cells (11). However, researchers informed that rods and rings autoantibody positive cases are mostly received interferon treatment. Rods and rings antibody-positive patients give weaker response to therapy than the others (27). Conversely, Carcamo et al. (28) reported $8 / 23$ persons who had rods and rings antibody without prior HCV infection. Although the prevalence was notably low, the primary reason for rods and rings antibody was found to be ribavarin and interferon combination therapy (29). In this study there were 3 patients that rods and rings antibody-positive and all of them were treated with ribavirin and interferon therapy.

\section{Conclusion}

This article shared 6-year experience associated with rare autoantibody patterns. It can be thought that rare ANA patterns do not have clinical importance; however, it should be considered with clinical and laboratory findings. In addition, our results showed that some rare ANA patterns, particularly mitotic patterns may be associated with non autoimmune conditions. The limitation of our analysis is the lack of detailed clinical findings of the patients. Notwithstanding, our laboratory is in a hospital which admits patients from Turkey's different regions. Therefore, this study's retrospective evaluation is worthy of attention. The significance of our results also emanates from the fact that they document a tertiary hospital's epidemiological data in Turkey.

Ethics Committee Approval: Ethics Committee Approval was not received due to the retrospective nature of the study.

Peer-review: Externally peer-reviewed.

Author Contributions: Evaluation of the patterns, data collection and writing -A.G.S.

Conflict of Interest: No conflict of interest was declared by the author.

Financial Disclosure: The author declared that this study has received no financial support. 


\section{References}

1. Vermeersch P, Bossuyt X. Prevalence and clinical significance of rare antinuclear antibody patterns. Autoimmun Rev 2013;12:998-1003. [CrossRef]

2. Sener AG, Afsar I, Demirci M. Evaluation of antinuclear antibodies by indirect immunofluorescence and line immunoassay methods: four years' data from Turkey. APMIS 2014;122:1167-1170. [CrossRef]

3. Şener AG, Afşar I. Frequency of dense fine speckled pattern in immunofluorescence screening test. Eur J Rheumatol 2015;2:103105. [CrossRef]

4. Skop AR, Liu H, Yates J 3rd, Meyer BJ, Heald R. Dissection of the mammalian midbody proteome reveals conserved cytokinesis mechanisms. Science 2004;305:61-66. [CrossRef]

5. Glotzer M. The molecular requirements for cytokinesis. Science 2005;307:1735-1739. [CrossRef]

6. Fang F, Wang HL, Ye P, et al. Detection of autoantibodies in the serum of primary hepatocarcinoma patients. Hepatobiliary Pancreat Dis Int 2002;1:94-95.

7. Granito A, Muratori L, Muratori $\mathrm{P}$, et al. Antibodies to filamentous actin (F-actin) in type-1 autoimmune hepatitis. J Clin Pathol 2006;59:280-284. [CrossRef]

8. Himoto $T$, Fujita $K$, Nomura $T$, et al. Diagnostic Dilemma in the Detection of Antibodies to Filamentous Actin. Clin Lab 2016;62:839847.

9. Schotte H, Willeke P, SchmalhorstJ, Schlüter B. Diagnostic Performance of an Anti-Actin Autoantibody Binding Enzyme Immunodot Blot in Autoimmune Hepatitis Type 1. J Clin Lab Anal 2016;30:123-129. [CrossRef]

10. Couto CA, Bittencourt PL, Porta G, et al. Antismooth muscle and antiactin antibodies are indirect markers of histological and biochemical activity of autoimmune hepatitis. Hepatology 2014;59:592-600. [CrossRef]

11. Chan EK, Damoiseaux J, Carballo OG, et al. Report of the First International Consensus on Standardized Nomenclature of Antinuclear Antibody HEp-2 Cell Patterns 2014-2015. Front Immunol 2015;6:412. [CrossRef]

12. Mack GJ, Rees J, Sandblom O, Balczon R, Fritzler MJ, Rattner JB. Autoantibodies to a group of centrosomal proteins in human autoimmune sera reactive with the centrosome. Arthritis Rheum 1998;41:551-558. [CrossRef]

13. Hamaguchi $Y$, Matsushita $T$, Hasegawa $M$, et al. High incidence of pulmonary arterial hypertension in systemic sclerosis patients with anti-centriole autoantibodies. Mod Rheumatol 2015;25:798-801. [CrossRef]

14. Terreri T, Niederhoff A, Zabel M, Blum U, Peter HH. Anti-centriole antibodies and high neuron-specific enolase activity in a patient with Raynaud phenomenon, cerebrovascular lesions, and ischemic finger necrosis -a functional relationship? Immun Infekt 1993;21 Suppl $1: 22-23$
15. Rodríguez JL, Gelpi C, Thomson TM, Real FJ, Fernández J. Anti-golgi complex autoantibodies in a patient with Sjögren syndrome and lymphoma. Clin Exp Immunol 1982;49:579-586.

16. Fritzler MJ, Etherington J, Sokoluk C, Kinsella TD, Valencia DW. Antibodies from patients with autoimmune disease react with a cytoplasmic antigen in the Golgi apparatus. J Immunol 1984;132:2904-2908.

17. Seelig HP, Schranz P, Schröter H, Wiemann C, Renz M. Macrogolgin -a new 376 kD Golgi complex outer membrane protein as target of antibodies in patients with rheumatic diseases and HIV infections. J Autoimmun 1994;7:67-91.

18. Hong HS, Chung WH, Hung SI, Chen MJ, Lee SH, Yang LC. Clinical association of anti-golgi autoantibodies and their autoantigens. Scand J Immunol 2004;59:79-87.

19. Hattori $H$, Nagata $E$, Ishihara $T$, et al. Inflammatory myopathy with anti-Golgi antibody and anti-SS-A/Ro antibody. Intern Med 2007:46:1927-1930.

20. Mozo L, Simó A, Suárez A, Rodrigo L, Gutiérrez C. Autoantibodies to Golgi proteins in hepatocellular carcinoma: case report and literature review. Eur J Gastroenterol Hepatol 2002;14:771-774.

21. Bonaci-Nikolic B, Andrejevic S, Bukilica M, Urosevic I, Nikolic M. Autoantibodies to mitotic apparatus: association with other autoantibodies and their clinical significance. J Clin Immunol 2006;26:438-446. [CrossRef]

22. Chan EK, Damoiseaux J, de Melo Cruvinel W, et al. Report on the second International Consensus on ANA Pattern (ICAP) workshop in Dresden 2015. Lupus 2016;25:797-804. [CrossRef]

23. Miyachi K, Fritzler MJ, Tan EM. Autoantibody to a nuclear antigen in proliferating cell. J Immunol 1978;121:2228-2234.

24. Beyne-Rauzy $O$, Thébault $S$, Adoue D, Fortenfant F. Anti-PCNA antibodies: prevalence and predictive value. Joint Bone Spine 2005;72:432-435. [CrossRef]

25. Fredi $M$, Cavazzana I, Quinzanini $M$, et al. Rare autoantibodies to cellular antigens in systemic lupus erythematosus. Lupus 2014;23:672-677. [CrossRef]

26. Vermeersch P, De Beeck KO, Lauwerys BR, et al. Antinuclear antibodies directed against proliferating cell nuclear antigen are not specifically associated with systemic lupus erythematosus. Ann Rheum Dis 2009;68:1791-1793. [CrossRef]

27. Stinton LM, Myers RP, Coffin CS, Fritzler MJ. Clinical associations and potential novel antigenic targets of autoantibodies directed against rods and rings in chronic hepatitis C infection. BMC Gastroenterol 2013;13:50. [CrossRef]

28. Carcamo W, Ceribelli A, Chan J, et al. Autoantibodies to a novel cytoplasmic Rod/Ring structure target CTP/GTP synthetic pathway in HCV infection after Interferon/Ribavirin therapy. Arthritis Rheum 2010;62(Suppl 10):1639.

29. Shaikh Y, Krantz A, El-Farra Y. Anti-rods and rings autoantibodies can occur in the hepatitis C-naïve population. J Prev Med Hyg 2013;54:175-180. 